\title{
Effect of Corporal Punishment on Students' Motivation and Classroom Learning
}

\author{
Iqbal Ahmad ${ }^{1}$, Hamdan Said ${ }^{1} \&$ Faisal Khan $^{2}$ \\ ${ }^{1}$ Faculty of Education, Universiti Teknologi Malaysia, Malaysia \\ ${ }^{2}$ Faculty of Management, Universiti Teknologi Malaysia, Malaysia \\ Correspondence: Iqbal Ahmad, Faculty of Education, Universiti Teknologi Malaysia, Johor Bahru, Skudai, \\ Malaysia. E-mail: shahnavi777@hotmail.com
}

$\begin{aligned} & \text { Received: July 16, } 2013 \quad \text { Accepted: August 15, } 2013 \quad \text { Online Published: August 20, } 2013 \\ & \text { doi:10.5539/res.v5n4p130 }\end{aligned} \quad$ URL: http://dx.doi.org/10.5539/res.v5n4p130

\begin{abstract}
This study examined the effect of corporal punishment on students' motivation and classroom learning. Research has indicated that behavior of teacher profoundly influences students' learning. It has been observed with great concern that teachers in Pakistani schools resort to corporal punishment to motivate students for classroom learning. Over the years this practice has resulted in reduced students' motivation towards learning. This study was purposefully designed to investigate this area of concern. For this purpose, the study attempted to find answer to the question that was there any relationship between corporal punishment and students' motivation and classroom learning. Using a correlation design, the study surveyed attitudes of a randomely sampled 250 teachers from secondary schools in Malakand district, Khyber Pakhtunkhwa, Pakistan. For data analysis, SPSS was used. This research studied the relationship between the following three main variables: corporal punishment as independent variable and student motivation and classroom learning as dependent variables. To examine correlation between the variables, ANOVA and Regression Analysis were utilized. Results of the study revealed that corporal punshment was significantly negatively correlated with students' motivation and classroom learning.
\end{abstract}

Keywords: effect, corporal punishment, student motivation, classroom learning

\section{Introduction}

Students who are physically punished develop negative attitudes towards learning. Even such students when develop into adult possess no empathy for others. Research has shown that children who are beaten up by their teachers learn aggression (Boser, 2001; Friedman \& Schonberg, 1996). They develop low self concept and see aggression as a means to solve problems of life. Studies further indicated that corporal punishment intimidates children. They develop low self-esteem and show dejection and hesitation to participate in learning activities (Flynn, 1994; Brezina, 1999; Straus, 2003). This type of behavior has wider implications as it leads to bigger violence later stages of life (Patel, 2003). The use of corporal punishment inculcates a strong belief in the impressionable minds of students that force is justified to control unwanted or undesirable behaviors. Ultimately, this promotes the attitudes of children that use of force or aggression is an acceptable act in the society (Straus, 1991; Baumrind, 1996; Roos, 2003). According to Roussow (2003) students who receive corporal punishment show symptoms of dejection in studies, poor performance in the tests and also do not participate in the teaching and learning process enthusiastically.Morrel (2000) found that use of corporal punishment influences attendance of school children. Students remain absent from school and this situation of longer absenteeism leads to withdrawal from schools. According to Vally (1998) the effects of physical punishment of students develop more severe psychiatric and traumatic conditions in children. Students in such an environment consider schools to be an unsafe place and thus they avoid coming to schools. This type of attitude of students is the direct result of harsh corporal punishment and unsupportive learning environment where physical punishment is the norm (Gershoff, 2002; Kaur, 2005; Tharps, 2003) Attitude of students towards learning depends upon many factors such as classroom environment, teacher attitude, curriculum and resources. According to Daskalogianni and Simpson (2000) attitude towards learning means the pattern of students' beliefs and emotions associated with classroom environment. Hannulla (2002) found that students' performance, efficacy, motivation and achievement in different subjects are essentially related to their attitude towards learning. 
Mitchell (1999) argued that students' attitude towards learning is closely connected to their academic success in that particular subject. The role of teacher in providing guidance to students regarding understanding of a subject is highly crucial and it determines the degree of the motivation of students toward learning of that subject. Gracia and Herrero (2006) found that teacher attitude and beliefs deeply influence students' attitude towards learning. In this regard this same writer further elaborates that the clarity of teachers' instruction deeply influences students' understanding of concept and their attitude towards learning in a subject.Swan, Bell, Phillips, and Shannon, (2000) argued that size of the class and its environment also determines students' attitude toward learning. In a friendly and spacious classroom environment, students take interest in the activities. Whereas, in an authoritarian and rigid classroom, student feel dejected and less actively participate in the learning process. Whiten (2007) found that commitment, care and help from teacher's side ensure student's conceptual understanding of a subject. Students who enjoy learning of a subject perform better than those students who do not. In this regard, the factor of enjoyment increases motivation of level of students. Gunnoe \& Mariner (1997) articulated that poor attitudes of students in a subject and high anxiety are associated with attitude of teachers towards students and students' own attitude towards the subject.Cater and Norwood (1997) discovered that home environment, educational background of parents and society also some of the factors that influence the attitudes of students toward learning. Earnest (2004) pointed out toward the general public image of mathematics as a subject in the minds of students and teachers alike that it is a dry subject. Students do not take high interest in it.However, despite the difficult nature of the subject of mathematics, many students continue to like it and have relatively positive attitude towards it. In this regard, the role of teacher is highly important (Rice, 1987; Iqbal, 2003). Teachers can promote the interest of students towards learning by creating a friendly, motivating and interesting teaching and learning environment in a classroom, where students feel safe, encouraged and respected (Cohen, 1996; Ma and Kishor, 1997; Richards, 2003).

On the basis of the above literature review, the following framework was deigned to conduct the study.

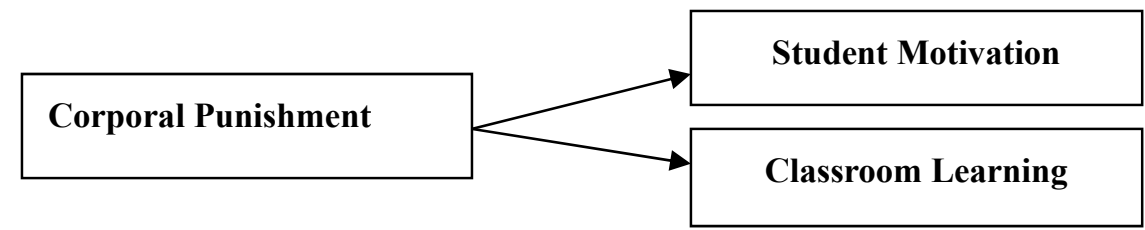

Figure 1. Conceptual framework

This current research framework draws its theoretical foundation from the Maslow theory of motivation. This theory places human needs in a hierarchical form. According to this theory, students cannot reach the highest goals of life until their basic needs are not satisfied. This study is based on the presumption that before preparing students for the classroom learning it is necessary to encourage them so that they are motivated for learning. Bandura (1977) also considers students' motivation necessary for classroom learning.

\section{Research Objectives}

1. To investigate the relationship between corporal punishment and student's motivation.

2. To investigate the relationship between corporal punishment and student's classroom learning.

\section{Research Questions}

1. Is there a relationship between corporal punishment and student motivation?

2. Is there a relationship between corporal punishment and student classroom learning?

\section{Research Hypotheses}

\section{H1. There is a relationship between corporal punishment and student motivation.}

H2. There is a relationship between corporal punishment and classroom learning.

\section{Methodology}

Using a correlation design, this study surveyed perceptions of 250 secondary school teachers in Khyber Pakhtukhwa, Pakistan. A self-administered questionnaire was used to collect data. Statistical software SPSS was used to analyze the data. The data items consisted of three main variables with corporal punishment as independent variable and student motivation and classroom learning as dependent variables. To examine the relationship between the stated research variables, ANOVA was used along with Regression Analysis. 


\section{Analysis of Data}

The purpose of this study was to examine the effects of corporal punishment on student motivation and classroom learning.

\section{Correlation Analysis}

Correlation analysis was conducted to examine the relationship between independent variable (Corporal Punishment) and the dependent variables (student motivation and classroom learning).

Table 1. Correlation between corporal punishment, student motivation and classroom learning

\begin{tabular}{llll}
\hline Variables & Corporal Punishment & Student Motivation & Classroom Learning \\
\hline Corporal Punishment & 1 & & \\
Student Motivation & $-0.783^{*}$ & 1 & \\
Classroom Learning & -0.674 & -0.676 & 1 \\
\hline
\end{tabular}

*Correlation is significant at the 0.01 level (2-tailed).

Table 1 show that independent variable (corporal punishment) is negatively correlated with student motivation and significant at $p<$ value of 0.01 . Corporal punishment has also a significantly negative correlation with student classroom learning through Pearson correlation values and significant at $\mathrm{p}<$ value of 0.01 .

\section{Regression Analysis}

Regression analysis was measured by testing the research hypotheses. The results for each variable are discussed as under.

$\boldsymbol{H}_{1}$ : There is a relationship between corporal punishment and student motivation

Table 2. Regression analysis of corporal punishment and student motivation

\begin{tabular}{llllll}
\hline Variables & R square & t-value & Coefficient & F-value & P value \\
\hline Corporal punishment & 0.612 & 14.33 & 0.71 & 269.0 & 0.00 \\
\hline
\end{tabular}

Table 2 shows that the value of coefficient beta is calculated as 0.71 that there is a significant relationship between the variables. The value of R-square is calculated as 0.612 showing $61.2 \%$ variation in the dependant variable (student motivation) is explained by independent variable (corporal punishment). The model's goodness of fit is shown by F-value that is 269.0. Hence, hypothesis 1 was accepted that corporal punishment was significantly negatively correlated with student motivation.

$\mathrm{H}_{2}$ : There is relationship betweencorporal punishment and student classroom learning

Table 3. Regression analysis of corporal punishment

\begin{tabular}{llllll}
\hline Variables & R square & t-value & Coefficient & F-value & P value \\
\hline Corporal punishment & 0.641 & 17.33 & 0.67 & 274.1 & 0.00 \\
\hline
\end{tabular}

Table 3 shows that the value of coefficient beta is measured as 0.67 that there is a significantly negative relationship between the variables. The value of $\mathrm{R}$-square is calculated as 0.641 showing $64.1 \%$ variation in the dependant variable (classroom learning) is explained by independent variable (corporal punishment). The model's goodness of fit is shown by F-value that is 274.1. Therefore, hypothesis 2 was accepted that corporal punishment was significant negatively correlated with student classroom learning.

\section{Discussion and Conclusions}

The purpose of this study was to investigate the effects of corporal punishment on student motivation and classroom learning. Major findings of the study are as follows;

1. Firstly, the study found that there was a significantly negative correlation between corporal punishment and student motivation. 
2. Secondly, the study also discovered that there was a significantly negative correlation between corporal punishment and student classroom learning.

On the basis of the results of this study it can be concluded that students who are subjected to corporal punishment are less motivated toward learning than those who are encouraged and not corporally punished. Students who are punished and discouraged hesitate to actively participate in classroom activities. This greatly decreases their motivation level for learning. It is suggested that teachers should avoid corporal punishment to maintain discipline or to ensure student learning. Instead, teachers may look for other positive alternatives such as student engagement, field work, case study method and project based activities through creating a supportive learning environment. This may help in learning sustainability of students.

\section{Recommendations for Future Research}

This was a cross-sectional survey research. For this purpose, data were collected only once during the study. It used only questionnaire as a data collection tool. Furthermore, the study had limitedsample size, time and finance. It is suggested that future research may use large sample size and data collection tools. This will help ensure reliability of data and generalization of the findings to other setting.

\section{References}

Bandura, A., \& Addams, N. E. (1977).Analysis of Self-Efficacy Theory of Behavioral Change. Cognitive Therapy and Research, 1(4). http://dx.doi.org/10.1007/BF01663995

Baumrind, D. (1996). A Blanket Injunction against Disciplinary use of Spanking is not warranted by the data. Pediatrics, 98(4).

Boser, U. (2001). The Unsparing Rod: Schools are still Fighting the Right to Paddle. U.S. News and World Report (p. 43). Washington.

Brezina, T. (1999). Teenage Violence towards Parents as an Adaptation to Family. Youth and Society, 30, 416-444. http://dx.doi.org/10.1177/0044118X99030004002

Cater, G. S., \& Norwood, K. S. (1997). The Relationship between Teacher and Student Belief about Mathematics. School Science and Mathematics, 97(2), 30-45.

Cohen, S. (1996). Teachers and Pupils Attitudes and Practices Regarding the Abolition of Corporal Punishment in schools in the Gauteng Area. Unpublished Masters Research.

Daskalogianni, K., \& Simpson, A. (2000). Towards a Definition of Attitude: the Relationship between the Affective and the Cognitive in Pre-university Students. Proceedings of PME, 24(2), 170-184.

Ernest, P. (2004). Images of Mathematics, Values and Gender. In S. Johnston-Wilder, \& B. Allen (Eds.), Mathematics education: exploring the culture of learning. Routledge.

Flynn, C. P. (1994). Regional Differences in Attitudes toward Corporal Punishment. Journal of Marriage and the Family, 56, 330-344. http://dx.doi.org/10.2307/353102

Gershoff, E. T. (2002). Corporal Punishment by Parents and Associated Child Behaviours andExperiences: A Meta- Analytic and Theoretical Review. Psychological Bulletin, 124(4). http://dx.doi.org/10.1037//0033-2909.128.4.539

Gracia, E., \& Herrero, J. (2006). Beliefs in the Necessity of Corporal Punishment of Children and Public Perception of Child Physical Abuse as a Social problem. Child Abuse and Neglect, 32. http://dx.doi.org/10.1016/j.chiabu.2008.05.004

Gunnoe, M. L., \& Mariner, C. L. (1997).Towards a Developmental-Contextual Model of the Effects of Parental Spanking on Children's Aggression. Archives of Pediatricand Adolescent Medicine (pp. 134-161). http://dx.doi.org/10.1001/archpedi.1997.02170450018003

Hannula, M. (2002). Attitude toward Mathematics: Emotions, Expectations, and Values. Educational Studies in Mathematics, 49, 22-29. http://dx.doi.org/10.1023/A:1016048823497

Iqbal, N. (2003). Rights-Pakistan: call to Spare the Rod in Schools Grows louder. Global Information Network (p. 1). New York.

Kaur, S. (2005).Wounded Innocence. The Tribune (Spectrum), 9, 1.

Ma, X., \& Kishor, N. (1997). Assessing the Relationship between Attitude Toward Mathematicsand Achievement in Mathematics: A Meta-Analysis. Journal for Research in MathematicsEducation, 28(1), 21-33. http://dx.doi.org/10.2307/749662 
Mitchell, T. (1999). Changing Student Attitudes Toward Mathematics. Primary Educator, 5(4), 4-11.

Morrel, R. (2000). Corporal Punishment.Education Monitor, 11(1), 42.

Patel, D. R. (2003). Corporal Punishment in Schools: Position paper of the Society for Adolescent Medicine. Journal of Adolescent Health, 32, 245-261.

Rice, J. E. (1987).The Attitudes of Teachers towards Corporal Punishment. Unpublished Masters Research.

Richards, P. (2003).Education-Trinidad: Support for Corporal Punishment Grows. Global Information Network (p. 12). New York.

Roos, R. (2003). Legal Requirements for School Rules and Disciplinary Sanctions. Koers, 68(4), 371-395. http://dx.doi.org/10.4102/koers.v68i4.353

Roussow, J. P. (2003). Learner discipline in South African Public Schools: A Qualitative Study. Koers, 68(4), 413-435.

Schoenfeld, A. (1985). Students' Beliefs about Mathematics and their Effects on Mathematical Performance: A Questionnaire Analysis. Paper presented at theAnnual Meeting of the American Educational Research Association, 23-34.

Straus, M. A. (1991). Discipline and Deviance: Physical Punishment of Children and Violence and other Crime in Adulthood. Social Problems, 38, 133-154. http://dx.doi.org/10.2307/800524

Straus, M. A. (2003). The Primordial Violence: Corporal Punishment by Parents, Cognitive Development, and crime. Walnut Creek CA: AltaMira press.

Swan, M., Bell, A., Phillips, R., \& Shannon, A. (2000).The Purpose of Mathematical Activities and Pupils' Perceptions of them. Research in Education, 63, 17-21. http://dx.doi.org/10.7227/RIE.63.2

Tafa, E. M. (2002). Corporal Punishment: The Brutal Face of Botswana's Authoritarian Schools. Education Review, 4(1).

Tharps, L. L. (2003). The Truth about Spanking. Essence, 33(1).

Vally. S. (1998). Spare the Child and Spoil the Rod. Educators Voice, 2(8). Retrieved May 8, 2004, from http://education.qld.gov.au/corporate/professional_exchange/edhistory/edhistopics/corporal/union.html

Whiten, P. (2007). The Mathematics Survey: A Tool for Assessing Attitudes and Dispositions. Teaching Children Mathematics, 13(8), 322-342. http://dx.doi.org/10.1080/00131910120110848

\section{Copyrights}

Copyright for this article is retained by the author(s), with first publication rights granted to the journal.

This is an open-access article distributed under the terms and conditions of the Creative Commons Attribution license (http://creativecommons.org/licenses/by/3.0/). 